\title{
Nutrient Removal and Algal Community Variation from Urban River with the Isolated Microalgal Strains Chlorella sp. and Scenedesmus sp.
}

\author{
Weiju Zhu' ${ }^{1}$, Yajun Li' ${ }^{1}$ Xiaowen Fei ${ }^{2}$, Xiaodong Deng ${ }^{1}$ \\ ${ }^{1}$ Institute of Tropical Bioscience and Biotechnology, Chinese Academy of Tropical Agricultural Science, Haikou, China \\ ${ }^{2}$ School of Science, Hainan Medical College, Haikou, China \\ Email: gdzxzwj@163.com
}

How to cite this paper: Zhu, W.J., Li, Y.J., Fei, X.W. and Deng, X.D. (2018) Nutrient Removal and Algal Community Variation from Urban River with the Isolated Microalgal Strains Chlorella sp. and Scenedesmus sp. Journal of Water Resource and Protection, 10, 884-895.

https://doi.org/10.4236/jwarp.2018.109051

Received: January 26, 2018

Accepted: September 11, 2018

Published: September 14, 2018

Copyright $\odot 2018$ by authors and Scientific Research Publishing Inc. This work is licensed under the Creative Commons Attribution International License (CC BY 4.0).

http://creativecommons.org/licenses/by/4.0/

\begin{abstract}
The objectives of this study were to determine nutrient removal rates and algal community variation using the isolated microalgal strains Chlorella sp. and Scenedesmus sp. from an urban river water. The concentration of total nitrogen (TN) and total phosphorus (TP) in river water declined after pouring into Chlorella sp. and Scenedesmus sp., it was indicated that the Scenedesmus sp. had respective advantage in removing nitrogen (86\% removal rate) and Chlorella sp. in removing phosphorous (95\% removal rate). The algae community composition showed extreme sensitivity to change in the joint of the Scenedesmus or Chlorella, respectively, the lower diversity and higher dominance of algae can be observed in Scenedesmus group, there existed an opposite tendency in Chlorella group. The results demonstrated that the high potential of using Chlorella sp. and Scenedesmus sp. for nutrient removal from riverwater.
\end{abstract}

\section{Keywords}

Nutrient Removal, Algae Community, Chlorella, Scenedesmus, Eutrophication

\section{Introduction}

Eutrophication caused by nutrient enrichment in most freshwater, coastal marine and transitional waters has become the tricky issues all over the world since the mid- $20^{\text {th }}$ century [1]. The adverse ecological impacts caused by eutrophication, such as reduction of biodiversity, increment of algae bloom, increased tur- 
bidity of the water, decreased crop of aquatic products, economic loss, have made tremendous efforts to control eutrophication [2] [3]). Nitrogen and phosphorus have been considered to be the key of eutrophication [4] [5] [6]. So the reducing the impacts of eutrophication especially nitrogen and phosphorus in water bodies is urgently need [7] [8].

Compared to the chemical and physical methods for the treatment of wastewater, biological treatment method is economical, especially bio-treatment with microalgae. There are extensive studies of nutrient removal based on algae growth in municipal [9] [10], agricultural [11] [12], and industrial wastewaters [13] [14]. Microalgae have been proved to be as a potential biological treatment material for wastewater [15] [16]. Tremendous efforts have been put into research of Chlorella or Scenedesmus removing nutrient from different wastewater. It was confirmed that, based on the nitrogen and phosphorous removal efficiencies, there was a range from $8 \%$ to $100 \%$ and from $30 \%$ to $100 \%$ in Chlorella and Scenedesmus, respectively. Lau et al. (1996) [17] found that Chlorella vulgaris can remove $86 \%$ inorganic $\mathrm{N}$ and $70 \%$ inorganic $\mathrm{P}$ in wastewater.

However, there is little attention for nitrogen and phosphorous removal in river. Because of industrialization and rapid economic development, rivers are been imposed severe risks. In this study, we applied the isolated microalgal strains Chlorella sp. and Scenedesmus sp. by experiments to river water from Meishe River in Haikou City, Hainan Province. The primary objectives of this study were to test the ability of microalgae removing nutrients in river, to identify the change of algae community. To our opinion, the microalgae can be as a candidate for application of river-water treatment.

\section{Methods}

\subsection{Sample Collection and Experiments Design}

The Meishe River with a drainage area of $50.16 \mathrm{~km}^{2}$, originates from the southern of Haikou City, Hainan Province, which flows into the Qiongzhou Strait after $23.86 \mathrm{~km}$. The water quality of river has deteriorated because of discharge of untreated sewage. Although the program for comprehensive management of Meishe River were launched, there are some challenges for improving water quality of river. So we collected the river water for nutrient removal experiments, the experiment used $250 \mathrm{ml}$ triangle vase filled with $200 \mathrm{ml}$ river water.

The experiments were divided two groups: one was planted with Chlorella sp., the other one was planted with Scenedesmus sp. The cell density of Chlorella sp. was set three level: $2 \times 10^{5}$ cells $/ \mathrm{ml}(\mathrm{C} 1), 6 \times 10^{5}$ cells $/ \mathrm{ml}(\mathrm{C} 2), 12 \times 10^{5}$ cells $/ \mathrm{ml}$ (C3). The cell density of Scenedesmus sp. was set three level: $2 \times 10^{5}$ cells $/ \mathrm{ml}$ (S1), $4 \times 10^{5}$ cells $/ \mathrm{ml}$ (S2), $6 \times 10^{5}$ cells $/ \mathrm{ml}$ (S3). Each experiment had 3 replications. Before each replication poured into algae, Chlorella sp. and Scenedesmus sp. were rinsinged with sterile water for eliminating the effects of nutrient from medium. The experiment lasted for 15 days, TN and TP measurement were conducted every five days. One the fifteenth day water samples were collected 
for quantitative analysis of algae community.

\subsection{Analysis of TN and TP}

TN and TP concentration was measured according to Chinese state standard testing methods [18].

Removal rates (\%) were calculated using relation shown in (1).

$$
R(\%)=\{(R t-R 0) / R t\} \times 100 \%
$$

where, $R$ is nutrient removal efficiency and $R t$ and $R 0$ are the nutrient concentration at day $t$ and day 0 , respectively.

\subsection{Analysis of Algae Community}

The water samples were preserved with Lugol's iodine and sedimented for more than $48 \mathrm{~h}$. The alga density was counted from $0.1 \mathrm{~mL}$ of the sediment through a $0.1 \mathrm{~mL}$ counting chamber using a microscope at $40 \times 10$ magnification. Alga taxa was identified to species or varieties according to Hu and Wei (2006) [19], and alga biomass was estimated according to the closest geometric shape of each taxa.

Species diversity index was calculated following Shannon-Wiener $(H)$, Simpson indices $(P)$ and Pielou evenness $(/)$ formula.

$$
\begin{gathered}
H=-\sum\left(n_{i} / N\right) \log _{2}\left(n_{i} / N\right) \\
P=1-\sum\left(n_{i} / N\right)^{2} \\
J=H / \ln S
\end{gathered}
$$

$N i=$ number of individuals of a species $i, N=$ total number of individuals.

\section{Results}

\subsection{The Change of TN and TP Concentration during the Experiment}

The TN concentration in river water declined after pouring into Chlorella sp. and Scenedesmus sp., S1 group obtained the higher ability for nitrogen removal on the tenth day, the TN concentration was only $0.81 \pm 0.20 \mathrm{mg} / \mathrm{l}$, TN removal rates reached $86 \%$. The TN concentration varied between $11.28 \mathrm{mg} / \mathrm{l}$ and 11.83 $\mathrm{mg} / \mathrm{l}$ in river water at the beginning of experiment.

Because of the different initial cell density, the variation of TN concentration in Scenedesmus groups and Chlorella groups demonstrated different tendency along with the experiment time. TN concentration declined on the fifth day and the tenth day, then increased on the fifteenth day in the group of S1, S2 and C2. $\mathrm{TN}$ concentration had a peak on the tenth day in the group of $\mathrm{C} 1$ and C3. However, TN showed a trend of increasing in the group of S3 (Figure 1).

The TP concentration in river water declined after pouring into Chlorella sp. and Scenedesmus sp., C1 group obtained the higher ability for phosphorous removal on the fifth day, the TP concentration was only $0.35 \pm 0.08 \mathrm{mg} / \mathrm{l}$, TP 


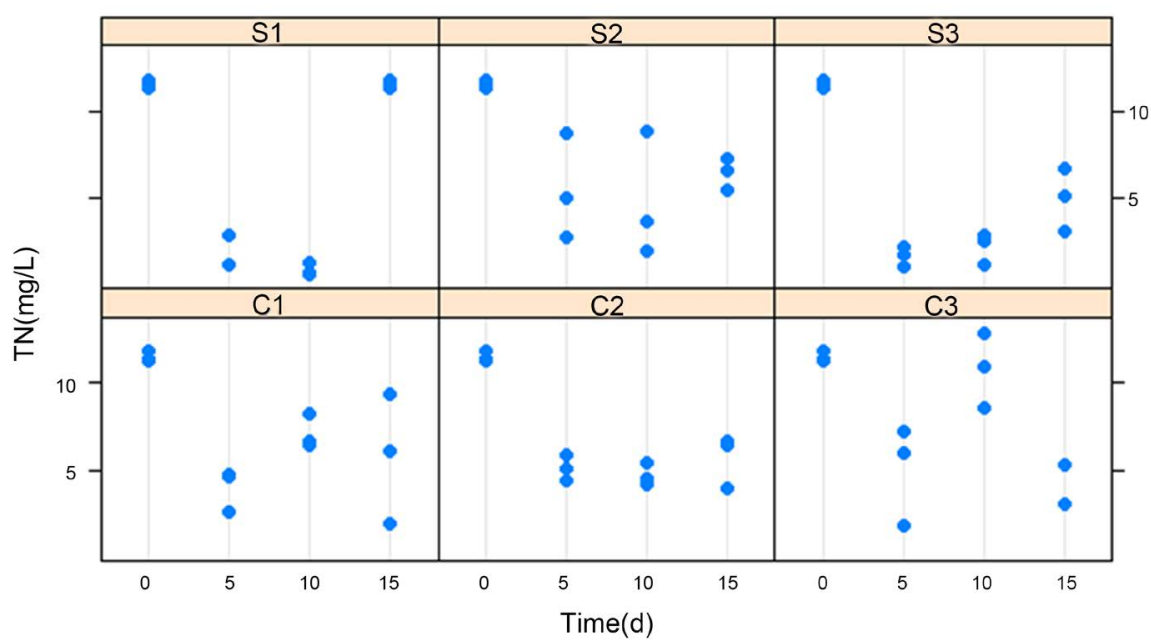

Figure 1. The variation of TN concentration with different initial cell density of Chlorella sp. and Scenedesmus sp.

removal rates reached $95 \%$. The TP concentration varied between $6.61 \mathrm{mg} / \mathrm{l}$ and $6.68 \mathrm{mg} / \mathrm{l}$ in river water at the beginning of experiment.

Although the different initial cell density, the variation of TP concentration in Scenedesmus groups and Chlorella groups demonstrated same tendency along with the experiment time. TP concentration had a peak on the tenth day in all groups (Figure 2).

\subsection{Algae Community Composition}

Species of algae in Chlorella group were significantly more than river-water, but those in Scenedesmus group were less than river samples (Table 1). A total of 27 taxa were detected in river samples, including 4 divisions 21 genera. In $S$ group, only 9 taxa were detected, including 3 divisions 6 genera. In $C$ group, a total of 62 taxa were detected, including 4 divisions 36 genera. Comparing to river samples, most algae (e.g. Melosira, Cyclotella, Navicula) disappeared in S group. However, many genera (e.g. Merismopedia, Anabaena, Fragilaria, Carteria, Tetraëdron, Oocystis, Pediastrum, Scenedesmus ) came out in C group.

The total of cell density was higher and Chlorophyta contributed more in Scenedesmus group (Figure 3). Bacillariophyta and Chlorophyta were the dominant groups in Chlorella group, Bacillariophyta contributed more in CK group (Figure 4). Nitzschia was the dominant species in CK, which contributed 54\% - 72\%, Nitzschia and Chlorella were the dominant species in C group, which contributed $37 \%, 21 \%$, respectively. Scenedesmus was the dominant species in S group, which contributed $97 \%$.

\subsection{Algae Community Diversity Index Change}

Compared to CK group, algae community diversity indexes increased in C group and declined in S group. The average Shannon-Wiener, Simpson indices and Pielou evenness increased 37\%, 28\%, and 18\%, respectively in C group. The 


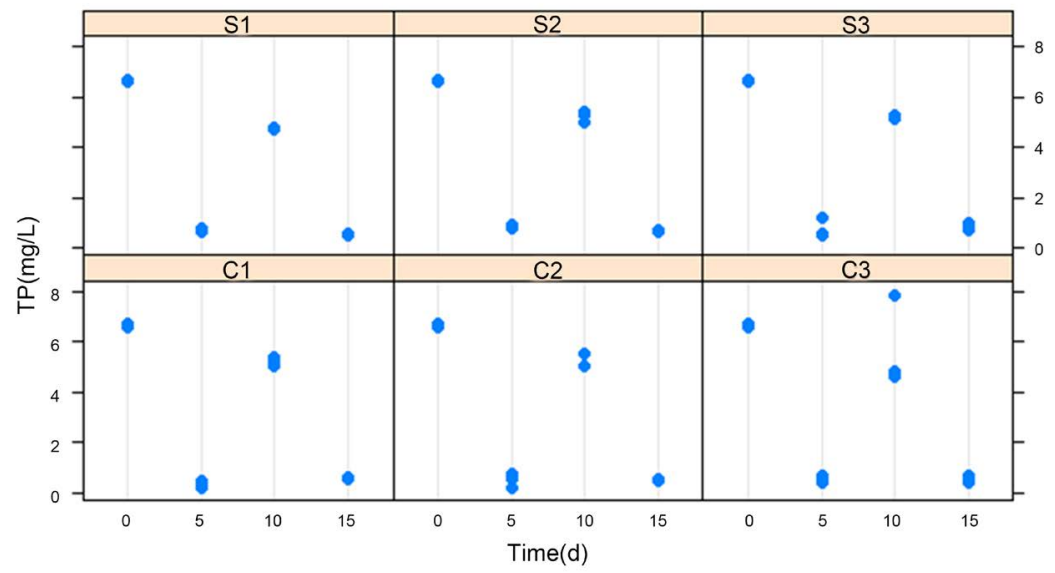

Figure 2. The variation of TP concentration with different initial cell density of Chlorella sp. and Scenedesmus sp.

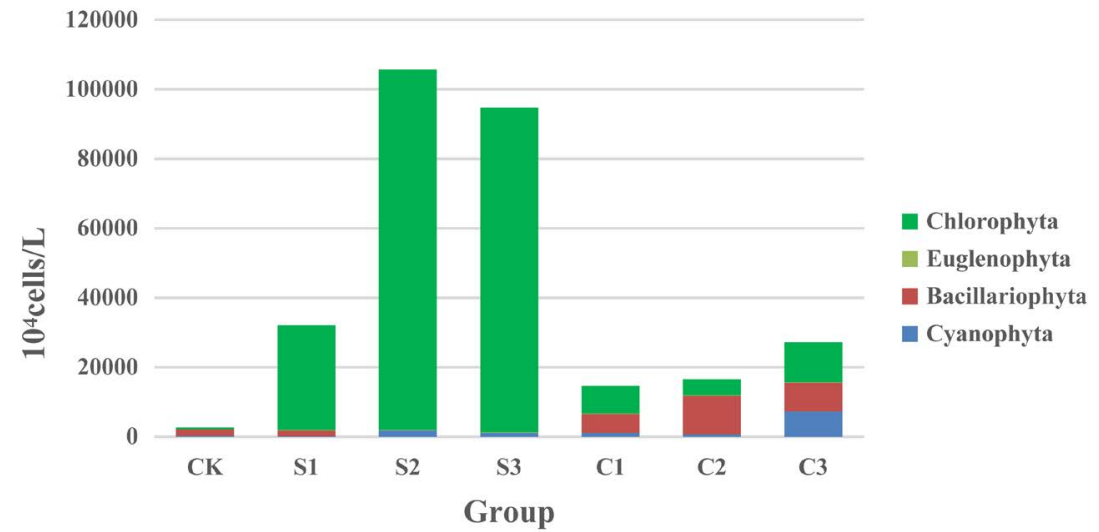

Figure 3. The variation of algae community with different initial cell density of Chlorella sp. and Scenedesmus sp.

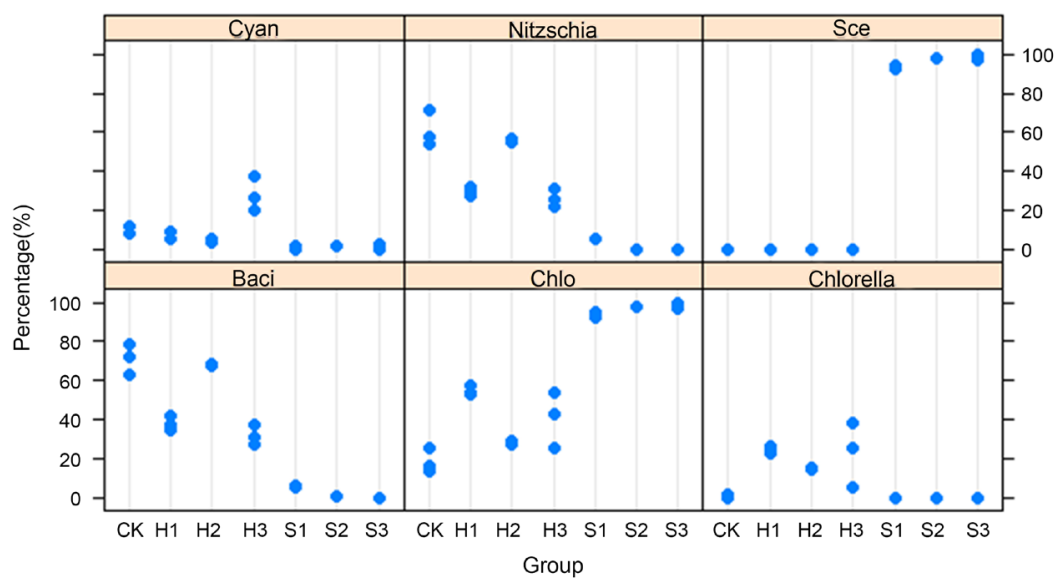

Figure 4. The percentage of algae community with different initial cell density of Chlorella sp. and Scenedesmus sp.

average Shannon-Wiener, Simpson indices and Pielou evenness decreased 90\%, $90 \%$, and $77 \%$, respectively (Figure 5). 


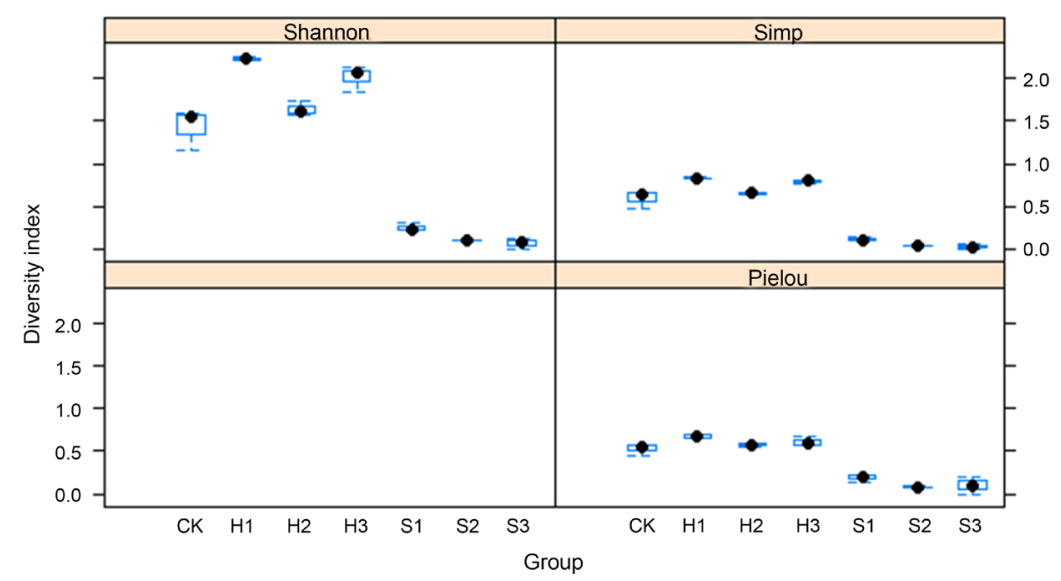

Figure 5. The change of algae community diversity with different initial cell density of Chlorella sp. and Scenedesmus sp.

Table 1. The list of algae in CK, S group and C group.

\begin{tabular}{|c|c|c|c|c|c|c|c|}
\hline \multirow{2}{*}{ Species list } & \multirow{2}{*}{$\mathrm{CK}$} & \multicolumn{3}{|c|}{ S group } & \multicolumn{3}{|c|}{ C group } \\
\hline & & 1 & 2 & 3 & 1 & 2 & 3 \\
\hline \multicolumn{8}{|l|}{ Cyanophyta } \\
\hline Chroococcus limneticus Lemmermann & & & & & & + & \\
\hline Merismopedia minima G. Beck & & & & & + & + & + \\
\hline Merismopedia punctata Meyen & & & & & & & + \\
\hline Lyngbya hieronymusii Lemmermann & & + & + & & & & \\
\hline Oscillatoria princeps Vaucher & & & & & & & + \\
\hline Oscillatoria sp. & + & & & + & + & + & \\
\hline Anabaena sphaerica Bornet et Flahault & & & & & & + & + \\
\hline \multicolumn{8}{|l|}{ Bacillariophyta } \\
\hline Melosira granulata (Ehr.) Ralfs & & & & & + & & \\
\hline Melosira granulata var.angustissima $\mathrm{O}$. Müller & + & & & & + & + & \\
\hline Melosira varians Agardh & & & & & + & & \\
\hline Cyclotella meneghiniana Kützing & + & & & & + & + & + \\
\hline Synedra acus Kützing & + & & & & + & & \\
\hline Synedra ulna (Nitzsch.) Ehrenberg & + & & & & & & + \\
\hline Synedra sp. & & & + & & & & \\
\hline Fragilaria capucina Deamaziéres & & & & & + & & \\
\hline Diploneis ovalis (Hilse) Cleve & + & & & & & & \\
\hline Navicula cryptocephala Kützing & + & + & & & + & + & + \\
\hline Navicula sp. & + & & & & & + & \\
\hline Pinnularia gibba Ehrenberg & & & & & & + & + \\
\hline Pinnularia sp. & & & & & & & + \\
\hline Amphora ovalis (Kütz.) Kützing & + & & & & & & \\
\hline Encyonema laten (Krasske) Mann & & & & & & & + \\
\hline Cocconeis placentula Ehrenberg & & & & & & & + \\
\hline
\end{tabular}




\section{Continued}

Gomphonema gracile Ehrenberg

Gomphonema gracile Ehrenberg

Achnanthes exigua Grunow

Nitzschia palea (Kütz.) W. Smith

Nitzschia scalpelliformis (Grunow) Grunow

Nitzschia sp.

Nitzschia sp.

Nitzschia sp.

Nitzschia sp

Nitzschia sp.

Euglenophyta

Trachelomonas sp.

Chlorophyta

Chlamydomonas globosa Snow

Carteria multifilis Dill

Micractinium crassisetum Hortobagyi

Golenkinia radiata Chodat

Schroderia setigera (Schroed.) Lemmermann

Chlorella vulgaris Beijrinck

Chodatella citriformis J. W. Snow

Tetraëdron trilobulatum (Reinsch) Hansgirg Ankistrodesmus acicularis (A. Braun) Korschikoff

Ankistrodesmus angustus Bernard

Kirchneriella lunaris (Kirch.) Moebius

Kirchneriella obesa (W. West) Schmidle

Quadrigula lacustris (Chodat) G. M. Smith

Oocystis lacustris Chodat

Oocystis sp.

Dictyosphaerium ehrenbergianum Nägeli

Dictyosphaerium pulchellum Wood

Pediastrum duplex Meyen

Pediastrum tetras var. tetraodon (Corda) Rabenhorst Scenedesmus sp.

Scenedesmus acuminatus (Lag.) Chodat

Scenedesmus bicaudatus (Hansgirg)Chodat

Scenedesmus biguga (Turp.) Lagerheim

Scenedesmus denticulatus Lagerheim

\section{$+$}

$+$

$+$

$+$

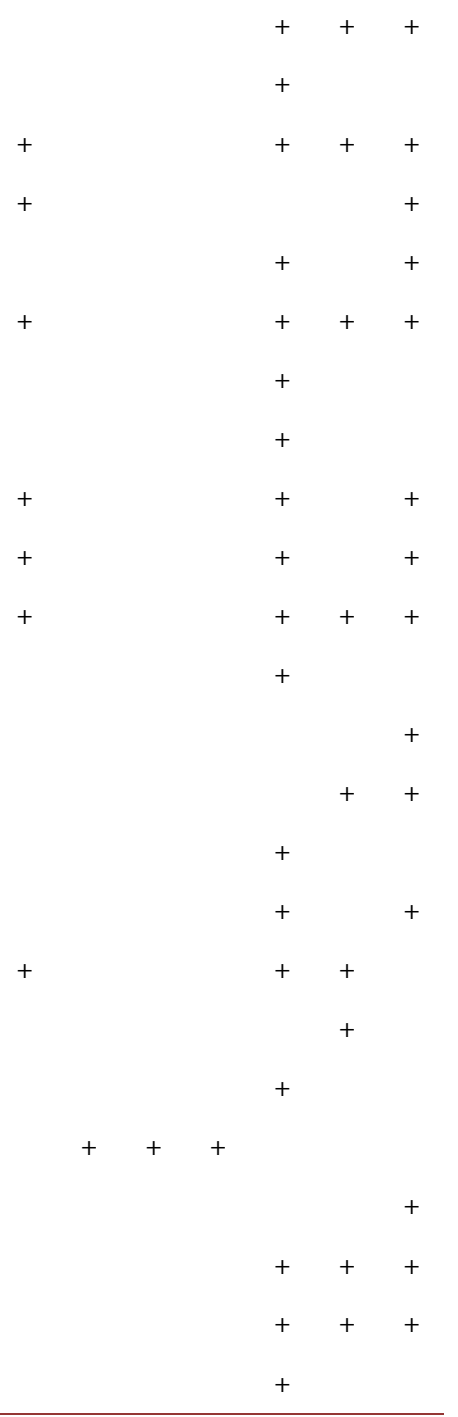




\section{Continued}

\begin{tabular}{|c|c|c|c|c|c|}
\hline Scenedesmus dimophus (Turp.) Kützing & & & & + & + \\
\hline Scenedesmus javaensis Chodat & & & + & & \\
\hline Scenedesmus protuberans Fritch & & & + & & \\
\hline Scenedesmus platydiscus (G. M. Smith) Chodat & & & + & & \\
\hline Scenedesmus quadricauda (Turp.) Brébisson & + & & + & + & + \\
\hline Scenedesmus serratus (Corda) Bohlin & & & + & & \\
\hline Tetrastrum elegans Playfair & + & & + & + & + \\
\hline Crucigenia tetrapedi (Kirchn.) West \& West & & & + & & + \\
\hline Crucigenia apiculata (Lemm.) Schmidle & + & & & & \\
\hline Actinastrum hantzschii Lagerheim & & & + & & \\
\hline Coelastrum sphaericum Nägeli & + & & + & & + \\
\hline Closterium gracile Brébisson & & & + & & \\
\hline \multirow[t]{2}{*}{ Staurastrum sp. } & & & & + & \\
\hline & 27 & 9 & & 62 & \\
\hline
\end{tabular}

\section{Discussion}

The success of applying microalgae to remove nitrogen or phosphorus from different wastewater has been demonstrated extensively [1] [20]). In our study, it was indicated that the nutrient removal rate from river water was different between Scenedesmus group and Chlorella group, the Scenedesmus sp. had respective advantage in removing nitrogen and Chlorella sp. in removing phosphorous (Figure 1). S1 group had the highest removal rate for TN on the tenth day, this suggests that Scenedesmus sp. with the initial cell density of $2 \times 10^{5}$ cells $/ \mathrm{ml}$ is likely to have a better TN removal effect. Álvarez-Díaz et al. (2017) [21] reported that Scenedesmus obliquus achieved higher daily nitrogen removal from wastewater than Chlorella kessleri, Chlorella vulgaris. Compared to free-living cells of Scenedesmus, the chitosan immobilized cells can accomplished a $70 \%$ nitrate and $94 \%$ phosphate removal within $12 \mathrm{~h}$ of incubation [22]. In the nitrogen/phosphorus ratio of 5:1 - 12:1, 83\% - 99\% nitrogen and 99\% phosphorus could be removed. The cells of Scenedesmus have the benefit of being equipped with spines and bristles, which make them more buoyant, increased nutrient uptake and avoid predation in the water [23] [24].

$\mathrm{C} 1$ group had the highest removal rate for TP on the fifth day, this suggests that Chlorella sp. with the initial cell density of $2 \times 10^{5}$ cells $/ \mathrm{ml}$ is likely to have a better TP removal effect (Figure 2) Chlorella is widely used in different type of wastewater treatment such as industrial wastewater, municipal wastewater, swine wastewater [25] [26], and it is shown to be effective in removing nitrogen and phosphorus. It is demonstrated that nitrogen and phosphorous removal efficiencies from the growth of Chlorella sp. range from $8 \%$ to $100 \%$ [1], and there exists some differences between different species of Chlorella. Some study con- 
firm that Chlorella vulgaris has higher nutrient removal efficiencies than that Chlorella kessleri when comparing their performances in artificial medium [27] [28]. In our study the TP removal efficiency of Chlorella reached 95\%, it can be a candidate species for removing the TP in river water. Su et al. (2011) [29] found that Chlorella pyrenoidosa in soybean processing wastewater obtained the faster removal of nitrogen over phosphorus. The ratio of N/P should be considered in order to ensure the simultaneous utilization of both nitrogen and phosphorus [30], an optimal N/P ratio for $C$. vulgaris was reported to be 7 [31].

There existed some differences in $\mathrm{S}$ group, $\mathrm{C}$ group and river sample, algae community composition showed extreme sensitivity to change in the joint of the Scenedesmus or Chlorella. Comparing to river sample, most algae (e.g. Melosira, Cyclotella, Navicula) disappeared in S group. However, many genera (e.g. Merismopedia, Anabaena, Fragilaria, Carteria, Tetraëdron, Oocystis, Pediastrum, Scenedesmus) came out and the diversity of algae increased in $\mathrm{C}$ group.

\section{Conclusions}

The study tested nutrient removal rates and algal community variation using the isolated microalgal strains Chlorella sp. and Scenedesmus sp. from an urban river water. The results showed:

1) The TN and TP concentration in river water declined after pouring into Chlorella sp. and Scenedesmus sp., the Scenedesmus sp. had respective advantage in removing nitrogen and Chlorella sp. in removing phosphorous. Scenedesmus sp. with the initial cell density of $2 \times 10^{5}$ cells $/ \mathrm{ml}$ is likely to have a better TN removal effect, TN removal rates reached $86 \%$. Chlorella sp. with the initial cell density of $2 \times 10^{5}$ cells $/ \mathrm{ml}$ is likely to have a better TP removal effect, TP removal rates reached $95 \%$.

2) Species of algae in Chlorella group were significantly more than river-water, but those in Scenedesmus group were less than river samples (Table 1). A total of 27 taxa were detected in river samples, including 4 divisions 21 genera. In $\mathrm{S}$ group, only 9 taxa were detected, including 3 divisions 6 genera. In $\mathrm{C}$ group, a total of 62 taxa were detected, including 4 divisions 36 genera. Comparing to river samples, most algae (e.g. Melosira, Cyclotella, Navicula) disappeared in Scenedesmus group. However, many genera (e.g. Merismopedia, Anabaena, Fragilaria, Carteria, Tetraëdron, Oocystis, Pediastrum, Scenedesmus ) came out in Chlorella group.

3) The total of cell density was higher and Chlorophyta contributed more in Scenedesmus group. Bacillariophyta and Chlorophyta were the dominant groups in Chlorella group, Bacillariophyta contributed more in CK group. Nitzschia was the dominant species in CK, which contributed 54\% - 72\%, Nitzschia and Chlorella were the dominant species in Chlorella group, which contributed 37\%, 21\%, respectively. Scenedesmus was the dominant species in Scenedesmus group, which contributed $97 \%$.

4) Compared to CK group, algae community diversity indexes increased in 
Chlorella group and declined in Scenedesmus group. The average Shannon-Wiener, Simpson indices and Pielou evenness increased 37\%, 28\%, and $18 \%$, respectively in $\mathrm{C}$ group. The average Shannon-Wiener, Simpson indices and Pielou evenness decreased $90 \%, 90 \%$, and $77 \%$, respectively.

In conclusion, this study showed that the Scenedesmus sp. had respective advantage in removing nitrogen and Chlorella sp. in removing phosphorous, the lower diversity and higher dominance of algae can be observed in Scenedesmus group, there existed an opposite tendency in Chlorella group.

\section{Acknowledgements}

The authors gratefully acknowledge anonymous reviewers. This project was supported by the Hainan Provincial Department of Science and Technology (ZDYF2016021).

\section{Conflicts of Interest}

The authors declare no conflicts of interest regarding the publication of this paper.

\section{References}

[1] Cai, T., Park, S. and Li, Y. (2013) Nutrient Recovery from Wastewater Streams by Microalgae: Status and Prospects. Renewable \& Sustainable Energy Reviews, 19, 360-369. https://doi.org/10.1016/j.rser.2012.11.030

[2] Paerl, H. (2009) Controlling Eutrophication along the Freshwater Marine Continuum: Dual Nutrient (N and P) Reductions Are Essential. Estuaries Coasts, 32, 593-601. https://doi.org/10.1007/s12237-009-9158-8

[3] Dodds, W., Bouska, W., Eitzmann J, et al. (2009) Eutrophication of U.S. Freshwaters: Analysis of Potential Economic Damages. Environmental Science and Technology, 43, 12-19. https://doi.org/10.1021/es801217q

[4] Prased, D. (1982) Effect of Phosphorus on Decomposition of Organic Matter in Fresh Water. Indian Journal of Environmental Health, 24, 206-214.

[5] Geddes, M. (1984) Limnology of Lake Alexandrina River, Muarry, South Australia and the Effect of Nutrients and Light on the Phytoplankton. Australian Journal of Marine and Freshwater Research, 35, 399-416. https://doi.org/10.1071/MF9840399

[6] Conley, D., Paerl, H., Howarth, R., et al. (2009) Controlling Eutrophication: Nitrogen and Phosphorus. Science, 323, 1014-1015. https://doi.org/10.1126/science.1167755

[7] Lewis, W., Wurtsbaugh, W. and Paerl, H. (2011) Rationale for Control of Anthropogenic Nitrogen and Phosphorus to Reduce Eutrophication of Inland Waters. Environmental Science Technology, 45, 10300-10305. https://doi.org/10.1021/es202401p

[8] Scott, J. and McCarthy, M. (2010) Nitrogen Fixation May Not Balance the Nitrogen Pool in Lakes over Timescales Relevant to Eutrophication Management. Limnology and Oceanography, 55, 1265-1270. https://doi.org/10.4319/lo.2010.55.3.1265

[9] Li, Y., Chen. Y., Chen, P., et al. (2011) Characterization of a Microalga Chlorella sp. Well Adapted to Highly Concentrated Municipal Wastewater for Nutrient Removal and Biodiesel Production. Bioresource Technology, 102, 5138-5144. 
https://doi.org/10.1016/j.biortech.2011.01.091

[10] Chi, Z., Zheng, Y., Jiang, A., et al. (2011) Lipid Production by Culturing Oleaginous Yeast and Algae with Food Waste and Municipal Wastewater in an Integrated Process. Applied Biochemistry and Biotechnology, 165, 442-453. https://doi.org/10.1007/s12010-011-9263-6

[11] Mulbry, W., Kondrad. S., Pizarro, C., et al. (2008) Treatment of Dairy Manure Effluent Using Freshwater Algae: Algal Productivity and Recovery of Manure Nutrients Using Pilot-Scale Algal Turf Scrubbers. Bioresource Technology, 99, 81378142. https://doi.org/10.1016/j.biortech.2008.03.073

[12] Mulbry, W., Kondrad, S., Buyer, J., et al. (2009) Optimization of an Oil Extraction Process for Algae from the Treatment of Manure Effluent. Journal of the American Oil Chemists' Society, 86, 909-915. https://doi.org/10.1007/s11746-009-1432-1

[13] Chinnasamy, S., Bhatnagar, A., Hunt, R. W., et al. (2010) Microalgae Cultivation in a Wastewater Dominated by Carpet Mill Effluents for Biofuel Applications. Bioresource Technology, 101, 3097-3105. https://doi.org/10.1016/j.biortech.2009.12.026

[14] Markou, G. and Georgakakis, D. (2011) Cultivation of Filamentous Cyanobacteria (Bluegreen Algae) in Agro-Industrial Wastes and Wastewaters: A Review. Applied Energy, 88, 3389-3401. https://doi.org/10.1016/j.apenergy.2010.12.042

[15] Oswald, W. and Gotaas, H. (1957) Photosynthesis in Sewage Treatment. Transactions of the American Society of Civil Engineers, 122, 73-105.

[16] Zhu, G., Peng, Y., Li, B., et al. (2008) Biological Removal of Nitrogen from Wastewater. Reviews of Environmental Contamination and Toxicology, 192, 159-195. https://doi.org/10.1007/978-0-387-71724-1_5

[17] Lau, P., Tam, N. and Wong, Y. (1996) Wastewater Nutrients Removal by Chlorella vulgaris: Optimization through Acclimation. Environmental Technology, 17, 183-189. https://doi.org/10.1080/09593331708616375

[18] NEPAC (The National Environmental Protection Agency of China) (2002) Standard Methods for the Examination of Water and Waste Water. 4th Edition, Chinese Environmental Science Press, Beijing.

[19] Hu, H. and Wei, Y. (2006) The Freshwater Algae of China Systematics, Taxonomy and Ecology. Sciences Press, Beijing.

[20] Mehrabadi, A., Farid, M. and Craggs, R. (2017) Potential of Five Different Isolated Colonial Algal Species for Wastewater Treatment and Biomass Energy Production. Algal Research, 21, 1-8. https://doi.org/10.1016/j.algal.2016.11.002

[21] Álvarez-Díaz, P., Ruiz, J., Arbib, Z., et al. (2017) Freshwater Microalgae Selection for Simultaneous Wastewater Nutrient Removal and Lipid Production. Algal Research, 24, 477-485. https://doi.org/10.1016/j.algal.2017.02.006

[22] Fierro, S., Sánchez-Saavedra, M. and Copalcúa, C. (2008) Nitrate and Phosphate Removal by Chitosan Immobilized Scenedesmus. Bioresource Technology, 99, 1274-1279. https://doi.org/10.1016/j.biortech.2007.02.043

[23] Konway, C. and Trainor, F. (1972) Scenedesmus Morphology and Flotation. Journal of Phycology, 8, 138-143. https://doi.org/10.1111/j.1529-8817.1972.tb01552.x

[24] Lürling, M. and Beekman, W. (1999) Grazer-Induced Defences in Scenedesmus (Chlorococcales; Chlorophyceae): Coenobium and Spine Formation. Phycologia, 38, 368-376. https://doi.org/10.2216/i0031-8884-38-5-368.1

[25] Godos, I., Blanco, S., Garcia-Encina, P., et al. (2009) Long-Term Operation of High Rate Algal Ponds for the Bioremediation of Piggery Wastewaters at High Loading Rates. Bioresource Technology, 100, 4332-4339. 
https://doi.org/10.1016/j.biortech.2009.04.016

[26] Kao, C., Chiu, S., Huang, T., et al. (2012) Ability of a Mutant Strain of the Microalga Chlorella sp. to Capture Carbon Dioxide for Biogas Upgrading. Applied Energy, 93, 176-183. https://doi.org/10.1016/j.apenergy.2011.12.082

[27] Lee, K. and Lee, C. (2001) Effect of Light/Dark Cycles on Wastewater Treatments by Microalgae. Biotechnology and Bioprocess Engineering, 6, 194-199. https://doi.org/10.1007/BF02932550

[28] Aslan, S. and Kapdan, I. (2006) Batch Kinetics of Nitrogen and Phosphorus Removal from Synthetic Wastewater by Algae. Ecological Engineering, 28, 64-70. https://doi.org/10.1016/j.ecoleng.2006.04.003

[29] Su, H., Zhang, Y., Zhang, C., et al. (2011) Cultivation of Chlorella pyrenoidosa in Soybean Processing Wastewater. Bioresource Technology, 102, 9884-9890. https://doi.org/10.1016/j.biortech.2011.08.016

[30] Li, X., Hu, H., Gan, K., et al. (2010) Effects of Different Nitrogen and Phosphorus Concentrations on the Growth, Nutrient Uptake, and Lipid Accumulation of a Freshwater Microalga Scenedesmus sp. Bioresource Technology, 101, 5494-5500. https://doi.org/10.1016/j.biortech.2010.02.016

[31] Shi, J., Podola, B. and Melkonian, M. (2007) Removal of Nitrogen and Phosphorus from Wastewater Using Microalgae Immobilized on Twin Layers: An Experimental Study. Journal of Applied Phycology, 19, 417-423.

https://doi.org/10.1007/s10811-006-9148-1 